\title{
Is Africa's Recent Growth Sustainable?
}

\author{
by \\ Thomas Barnebeck Andersen \\ and \\ Peter Sandholt Jensen
}

Discussion Papers on Business and Economics

No. $8 / 2013$

\author{
FURTHER INFORMATION \\ Department of Business and Economics \\ Faculty of Social Sciences \\ University of Southern Denmark \\ Campusvej 55 \\ DK-5230 Odense M \\ Denmark
}

Tel.: +456550 3271

Fax: +4565503237 


\title{
Is Africa's Recent Growth Sustainable?
}

\author{
Thomas Barnebeck Andersen \\ Department of Business and Economics, University of Southern Denmark, \\ Campusvej 55, DK-5230 Odense M, Denmark \\ Email: barnebeck@sam.sdu.dk \\ Peter Sandholt Jensen \\ Department of Business and Economics, University of Southern Denmark, \\ Campusvej 55, DK-5230 Odense M, Denmark \\ Email:psj@sam.sdu.dk
}

April 8, 2013

\begin{abstract}
In this paper we argue that the answer is yes. Our optimism rests on the finding that differences in the level of institutional quality predict cross-country variation in African economic growth during the period 1995-2011. This finding is quite robust. It holds in OLS, LAD and 2SLS settings; it holds for different measures of institutions and different measures of economic growth; and it holds for the period before and the period after the global financial crisis. We also show that changes in institutional quality predict cross-country variation in African economic growth. Moreover, if we split our sample in two equally sized groups, a high-growth and a low-growth group, then the high-growth group has experienced a statistically significant increase in institutional quality, whereas the low-growth group has not. Overall, this makes probable that institutions has played an important part in Africa's recent growth acceleration. The continent has seen many false dawns, caused in large part by ups in commodity prices, but a growth acceleration driven by institutions is likely to signify a genuine African takeoff.
\end{abstract}

JEL Classification: 011, 043, 047

Keywords: institutions; economic growth; Africa

We thank Jens Jakob Nordvig and Nikolaj Malchow-Møller for useful comments. Errors are ours. 


\section{Introduction}

Much has been said about the rise of the BRIC countries and the economic performance of several smaller Asian countries. As of late, however, Africa has joined the club of fast-growing regions. The IMF's World Economic Outlook (October 2012) projects Africa's real GDP growth for 2013 to be $5.7 \%$. With average real growth rates in the advanced economies running at $1.3 \%$, the African growth acceleration has caught widespread attention. ${ }^{1}$ A recent McKinsey Global Institute report on Africa speaks of "lions on the move", while the Economist (April 6th, 2013) sees in Africa the "hottest frontier" in terms of foreign investment. The new Chinese president stated in a recent speech in Tanzania-which, by the way, was part of his first overseas trip as head of state-that the "African lion is galloping faster and faster." ${ }^{2}$ For a continent that has experienced temporary growth accelerations before, caused in large part by fluctuations in commodity prices, a key question is whether the recent one is any different? Or, to put it differently, is Africa's recent growth sustainable?

The sustainability question is presently the focus of an active debate. In their recent survey of Sub-Saharan Africa, the Economist (March 2, 2013) captures the poles of the debate quite well. There are the "boosters", who proclaim the dawn of an African century; and there are the "skeptics", who see foreign investors as not lifting but looting the continent. ${ }^{3}$ The debate about growth sustainability is surely not made easier by the fact that economists have no theory of sustained economic growth.

In this paper we cautiously side with the optimists; that is, we argue that Africa's recent growth is sustainable. Our optimism rests on the finding that differences in the level of institutional quality predict cross-country variation in African economic growth during the period 1995-2011. ${ }^{4}$ This finding is quite robust. It holds in OLS, LAD and 2SLS settings; it holds for different measures of institutions and different measures of economic growth; and it holds for the period before and the period after the global financial crisis. We also show that changes in institutional quality predict cross-country variation in African economic growth. Moreover, if

\footnotetext{
${ }^{1}$ In the words of a recent leader in The Economist ("Aspiring Africa," March 2nd, 2013): "Never in the half-century since it won independence from the colonial powers has Africa been in such good shape." Indeed, the selfsame leader is subtitled "The world's fastest-growing continent." In Denmark, the Minister for Trade and Investment recently lamented Danish firms' reluctance to dealing with the continent and argued that they miss out on the huge potential in Africa ("Danske virksomheder går glip af Afrikas vækstboom," Politiken, March 26, 2013).

2 "China pledges more investment to Africa" (Financial Times, March 25, 2013).

${ }^{3}$ Lamido Sanusi, governor of the Central Bank of Nigeria, recently joined the choir of skeptics (see "Africa must get real about Chinese ties," Financial Times, March 11th, 2013). His critique triggered a response from Qu Xing, president of the China Institute of International Studies ("Africa and China are good for each other," Financial Times, April 5th, 2013).

${ }^{4}$ This period is an unusually interesting one to study. In the words of a recent leader in The Economist (Aspiring Africa, March 2nd, 2013): "Never in the half-century since it won independence from the colonial powers has Africa been in such good shape." Indeed, the selfsame leader is subtitled "The world's fastest-growing continent."
} 
we split our sample in two equally sized groups, a high-growth and a low-growth group, then the high-growth group has experienced a statistically significant increase in institutional quality, whereas the low-growth group has not. Overall, this makes probable that institutions has played an important part in Africa's recent growth acceleration. A consistent finding of two decades of economic research is that institutions matter for economic development (see Acemoglu 2009, Chapter 4, for a survey). Better institutions will encourage entrepreneurs to invest in capital and ordinary people to invest in human capital (Johnson, Ostry, and Subramanian 2007). Better institutions will also increase the likelihood of a smooth adjustment following an adverse shock, which otherwise could derail a nascent growth takeoff. Indeed, research has demonstrated that poor macroeconomic policy tends to reflect underlying institutional challenges (Acemoglu, Johnson, and Robinson 2003). ${ }^{5}$

Our paper is related to a recent literature that explores the factors explaining Africa's recent growth success. Beny and Cook (2009) have studied Africa's growth during the period 1960 to 2005. They show that property rights correlate with economic growth in Africa, but their main message is one of export growth. Leke, Lund, Roxburgh, and van Wamelen (2010) argue that two-thirds of Africa's growth came from internal structural changes, including government action to improve macroeconomic conditions and undertake microeconomic reforms to create a better business climate. Arbache and Page (2010) study Africa's growth between 1974 and 2005. They find that the recent growth was propelled by the rapid global demand for natural resources; and they also find a structural break in Africa GDP growth in the mid-1990s. Our paper is complementary to these papers in a number of respects: For instance, we use adjusted GDP data. More specifically, as suggested by Henderson, Storeygard, and Weil (2011), we combine PPP GDP data with nightlights from space in order to reduce measurement error. Moreover, our observation window begins in 1995, when there is a structural break in African GDP data (cf., Arbache and Page 2010), and it ends in 2011. This enables us to demonstrate that institutions have the same predictive power on both sides of the global financial crisis of 2007/08; a finding that squares quite well with the view that better institutions increase the likelihood of a smooth adjustment following an adverse shock (Johnson, Ostry, and Subramanian 2007).

Our paper is also related to the literature on long-run growth and development; a literature in which the view that institutions are the fundamental cause of development has been backed by a large amount of empirical research (e.g., Hall and Jones 1999; Acemoglu, Johnson, and Robinson 2001; Easterly and Levine 2003; Rodrik, Subramanian, and Trebbi 2004).

\footnotetext{
${ }^{5}$ The shift in focus in terms of economic policy reform from policies to institutions, which took place in the early 1990s, squares well with the above argument. The IMF's increasing use of structural reforms is a manifestation of this change of focus (See Independent Evaluation Offices 2008, http://www.ieoimf.org/ieo/pages/CompletedEvaluation111.aspx).
} 
By and large, the modus operandi of this research has been to regress the level of income per capita on (exogenous variation in) institutional quality and various controls. The logic is that institutions change very slowly, so if one conditions on initial income, as in a standard growth regression, or includes fixed effects it may be very difficult or impossible to uncover an effect from institutions to economic growth. That is, institutions are not generally expected to have discernible short-run effects. Our results show that this is not always so.

Finally, the paper is related to the policy literature that criticizes the singular focus on institutions and institutional reform. This literature emphasizes that it amounts to a bestpractice model, which presumes that it is possible ex ante to settle on a unique set of appropriate institutional arrangements (best-practices), and that convergence towards these institutional arrangements is attractive (Evans 2004; Bromley and Yao 2006; Rodrik 2006). This literature also emphasize that a singular focus on institutions and institutional reforms ignores the existence of country-specific binding constraints, ${ }^{6}$ and, by extension, a sense of reform priority. Hausmann, Pritchett, and Rodrik (2005) present empirical evidence that they interpret as being consistent with a generic presence of country-specific binding constraints. ${ }^{7}$ Finally, critics hold that the focus on best-practice institutions does not fit well with the fact that many "growth miracles" are characterized by "heterodox" institutional arrangements (Rodrik 2005). ${ }^{8}$ Our results warn against an excessive emphasis on country-specific binding constraints and heterodox institutional arrangements.

The paper is structured as follows. Section 2 presents our main empirical approach. Section 3 presents our results pertaining to the period prior to the global financial crisis, while section 4 presents post crisis results. Finally, section 5 concludes.

\section{Empirical approach}

We explain Africa's recent economic growth using a standard growth regression

\footnotetext{
${ }^{6}$ Collier (2007) provides an illustrative example of the country specificity of binding constraints. Bangladesh and Chad both have endemic corruption. Yet despite being a very corrupt country, Bangladesh has experienced decent growth. Chad, on the other hand, has not done well. According to Collier, this is due to differences in opportunities. Bangladesh is a resource-scarce, coastal, low-income country. Its development path is clear: export labor-intensive manufactures and services. This development strategy is not very demanding in terms of government. Not so for Chad, an oil-rich, aid-abundant, landlocked, low-income country. Chad is not well located for exporting, and to make good use of aid and oil requires a reasonably good government. That is, Chad's government must do more than "do-no-harm"; it must really do some good. Corruption is thus much more harmful for Chadians than for Bangladeshi. In other words, corruption is a binding constraint in Chad, but not in Bangladesh.

7 Specifically, they claim that growth accelerations are mainly caused by idiosyncratic, and often small-scale, changes; and they argue that this is consistent with the idea that a set of country specific binding constraints may in fact be holding down economies' growth rates.

${ }^{8}$ Some authors also emphasize the importance of building reforms on pre-existing institutions and making reforms incentive compatible (Qian 2003; Rodrik 2005).
} 
framework. Besides initial real GDP per capita, we control for institutions and natural resources. Institutional quality is a deep determinant of economic performance in the sense that good institutions ensure the enforcement of property rights, put constraints on the actions of politicians and other commanding groups, and ensure some degree of equal opportunity for broad segments of society (Acemoglu 2009). Indeed, poor macroeconomic policy often reflects underlying institutional deficiencies (Acemoglu, Johnson, and Robinson 2003). At the same time, we know that several African countries have benefitted substantially from high commodity prices during the period under consideration. According to the Economist, during the period 2000-2008 around a quarter of Africa's growth came from higher revenues from natural resources; Leke, Lund, Roxburgh, and van Wamelen (2010) argue that it was one-third. Whatever the case, high commodity prices stimulate growth in the short run regardless of institutional quality and so natural resources should be accounted for in the growth regression. Consequently, we estimate the following growth regression:

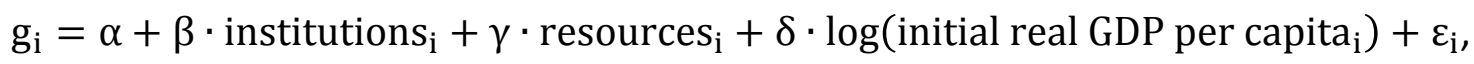

where $g_{i}$ is the average annual growth rate of real income per capita over the period 1995-2007 (we turn to the period 2008-2011 in Section 4). ${ }^{9}$

We follow the lead of Henderson, Storeygard, and Weil (2011) in producing adjusted real GDP per capita growth rates by employing satellite data on nightlights. Briefly, the growth observations used below are a convex combination (weight: 0.5 ) of observed real (chained PPP) GDP per capita growth (from Penn World Tables 7.0) and the fitted values from a regression of this variable on growth in nightlights. This adjustment is intended to reduce measurement error (for details, see Henderson, Storeygard, and Weil 2011).

We use two different measures of institutions. First and foremost, we follow Rodrik, Subramanian, and Trebbi (2004) in using the composite rule-of-law indicator, due to Daniel Kaufmann, Aart Kraay, and Massimo Mastruzzi, ${ }^{10}$ for the year 2001 as our institutional quality measure (Kaufmann, Kraay, and Mastruzzi 2010). According to Rodrik, Subramanian, and Trebbi, the year 2001 approximates for institutions in the 1990s, i.e. initial institutions in our sample period. The rule of law indicator captures perceptions of the extent to which agents have confidence in and abide by the rules of society, and in particular the quality of contract

\footnotetext{
${ }^{9}$ Equation (1) differs from the levels regression framework in that initial GDP per capita is included in the equation, effectively picking up long-run influences on growth. While we recognize the shortcomings of growth regressions on cross-country data (see Mankiw 1995 for a discussion), we also believe that-used carefully-the framework can be quite informative.

${ }^{10}$ The governance indicators are available at http://info.worldbank.org/governance/wgi/index.asp, though we have obtained the indicator from Dani Rodrik's webpage, where a replication dataset is available.
} 
enforcement, property rights, the police, and the courts, as well as the likelihood of crime and violence. ${ }^{11}$ It is a standardized measure, which varies between -2.5 (weakest institutions) and 2.5 (strongest institutions). In our sample, the range is between -1.50 (Guinea-Bissau) and 1.23 (Namibia).

While much of the literature on institutions and development has relied on the rule of law index, we would surely take more comfort if similar results emerge when using an alternative institutions measure. An obvious alternative, which is available through the World Development Indicators and which is one of thirty underlying sources used in the construction of the rule of law index, is the World Bank's Country Policy and Institutional Assessment (CPIA) index. ${ }^{12}$ Here we focus on the "CPIA public sector management and institutions cluster average" (1=low to $6=$ high), which includes property rights and rule-based governance, quality of budgetary and financial management, efficiency of revenue mobilization, quality of public administration, and transparency, accountability, and corruption in the public sector. The CPIA measure is not available before 2005, so we settle for that year. In our sample, CPIA ranges from 2.2 in Togo (the hindmost) and 3.9 in Cape Verde (the topmost).

We will use a measure of total natural resource rents (\% of GDP) in 2007. It measures the sum of oil rents, natural gas rents, coal rents, mineral rents, and forest rents, where rents are the difference between the value of production at world prices and their total costs of production. This variable is taken from World Development Indicators (2011).

Finally, to ensure conformity with the literature on comparative economic development, we instrument the level of institutional quality using the fraction of the population speaking a primary European language as first language (eurfrac). This instrument was proposed by Hall and Jones (1999) in their pioneering study of the role of institutions in economic development and subsequently used in an influential study by Rodrik, Subramanian, and Trebbi (2004). ${ }^{13}$ Table 1 provides summary statistics for the main variables.

\section{[Table 1 about here]}

\section{Main results}

\footnotetext{
${ }^{11}$ See http://info.worldbank.org/governance/wgi/pdf/rl.pdf. Rule of law as our institutions measure also fits well with North's (1990, p. 54) view that the "inability of societies to develop effective, low-cost enforcement of contracts is the most important source of both historical stagnation and contemporary underdevelopment in the Third World."

12 The CPIA enters the calculation of country performance ratings that, since 1980, have been used to allocate International Development Association resources to eligible client countries.

${ }^{13}$ Primary European languages are English, French, German, Portuguese, and Spanish.
} 
Table 2 reports our regression results when we employ the rule of law indicator. The dependent variable in columns 2 to 4 is nightlight adjusted real GDP per capita growth over the period 1995-2007; in column 1 we use unadjusted growth in real (PPP) GDP per capita for reasons of comparison. We immediately note that the R-squared is somewhat higher with adjusted growth, cf. column 2 . This is fully consistent with the notion that adjusted growth reduces measurement error. Moreover, with adjusted growth all variables in column 2 are significant and have the expected signs. Overall, the simple growth regression explains a decent $24 \%$ of the variation in growth in Africa over the period 1995-2007.

[Table 2 about here]

In column 3 we explore robustness of the specification in column 2 via the LAD (least absolute deviations) estimator. LAD minimizes the sum of absolute values of the residuals. Unlike OLS, LAD does not give increasing weights to larger residuals, for which reason it is much less sensitive to potential outliers. Under the maintained assumption that the errors are symmetrically distributed, we know from Wooldridge (2010) that LAD estimates both the conditional mean and the conditional median. Inspection of column 3 therefore reveals that LAD produces more or less the same conclusion as OLS in column 2. This is not surprising given the tight partial regression plot associated with column 2 of the table, cf. figure 1.

[Figure 1 about here]

Column 4 of table 2 reports 2SLS results with the language variable invoked as instrument for rule of law. The first thing to note is that the instrument is weak, which leads us to rely on the weak-identification robust Anderson-Rubin statistic. According to this statistic rule of law is significant at one percent. The numerical impact of institutions on growth more than quadruples; but as standard errors also more than quadruples, we cannot reject that rule of law is exogenous using the Wooldridge (1995) score test. That is, OLS and 2SLS estimates are not statistically different. A conservative approach, which we adhere to here, is then to use the OLS estimate in column 2 to gauge economic significance.

So how large is the effect of institutions on growth quantitatively? Using column 2 of table 2, we have that one standard deviation increase in rule of law leads to 0.55 standard deviations increase in adjusted growth. Initial GDP and natural resources have similar economic impacts: -0.55 and 0.50 , respectively. An alternative way to appreciate the economic significance of rule of law is to consider the counterfactual scenario in which Guinea-Bissau (the hindmost) would achieve the level of institutional quality of Namibia (the topmost). This move corresponds to an annual growth increase of 3.82 percentage points. Yet another way to 
appreciate the economic significance of rule of law is to invoke the neoclassical growth model. With the long-run growth rate exogenously given, changes in rule of law only have long-run levels effects. We obtain the long-run relation $\log ($ GDP per capita)=1.4-rule of law. The aforementioned counterfactual scenario would thus have raised the steady state level of GDP per capita by almost a factor $4 .^{14}$

In table 3 we re-estimate table 2 above using the alternative measure of institutions, namely CPIA. The correlation between rule of law and CPIA is 0.53 , cf. table 1 . Visually, the correlation is depicted in figure 2.

[Table 3 about here]

[Figure 2 about here]

Two things should be noted immediately upon inspecting table 3. First, we lose seven observations when we rely on CPIA. Second, results are fairly similar to those obtained in table 2. CPIA is significant in all columns, OLS slope estimates are slightly higher than in table 2 , and 2SLS are about the same. An important difference, however, is that we always have a strong instrument, in which case the usual standard errors in column 4 are appropriate. The 2SLS estimate is now about three times the size of the OLS counterpart and standard errors about double the size. However, we still cannot reject that the 2SLS estimate differs significantly from OLS. In terms of economic significance, results are also similar. Using column 2 of table 4, we have that one standard deviation increase in CPIA leads to 0.58 standard deviations increase in adjusted growth. The partial regression plot associated with column 2 of table 3 is depicted in figure 3.

[Figure 3 about here]

Since OLS and 2SLS estimates are not statistically different, we subject the OLS estimation in column 2 of tables 2 and 3 to some robustness checks in the appendix. Specifically, we show in appendix table A.1 that results are robust to the inclusion of lightning density, malaria ecology, and distance to the equator. Lightning density spans exogenous variation in power outages, which is one of the most important constraints for African SMEs (Andersen and Dalgaard 2013). ${ }^{15}$ Malaria ecology spans exogenous variation in the incidence of malaria;

\footnotetext{
${ }^{14}$ With a rate of convergence of $1 \%$, the implied convergence is quite slow (the half-life is 70 years).

${ }^{15}$ Lightning damage accounts for about $65 \%$ of all over-voltage damage to electrical distribution networks in South Africa; over-voltage damage in turn is thought to account for one-third of all outages. ${ }^{15}$ In Swaziland more than $50 \%$ of power outages on transmission lines are attributed to lightning (Mswane and Gaunt 2005). These numbers are roughly in line with (though somewhat bigger than) measurements reported for the U.S (McGranaghan et al. 2002;
} 
disease being a competing deep determinant of income vis-à-vis institutions (Sachs 2003). Distance to the equator captures, inter alia, distance to major markets, and as such spans exogenous variation in potential gains from trade (Hall and Jones 1999). We also check robustness to the inclusion of demographic variables such as the share of the population between 0-14 and 15-64, respectively, and the (log of) total population. These demographic variables are intended to capture demographic dividends and/or a scale effects. Demographic variables are from World Development Indicators 2012. As shown in appendix table A.2, inclusion of demographic variables also has no bearing on our results.

Before closing this section we need to address one remaining issue, namely the level of institutional quality (analyzed so far) versus the change in selfsame over the period 1995-2007. Since CPIA is available only back to 2005, we instead use rule of law to investigate this issue. Rule of law is available all the way back to $1996 .{ }^{16}$ Figure 4 provides a scatter plot of rule of law in 1996 versus 2007.

[Figure 4 about here]

The scatter plot reveals a high degree of institutional persistency; the correlation between rule of law in 1996 and 2007 is $\mathbf{0 . 8 2}$. Observations are tightly clustered around the 45degree line, suggesting little aggregate institutional change in Africa. The first obvious question to ask is then whether the continent as a whole has seen an increase in institutional quality of the period 1996-2007. As reported on the bottom line of table 4, the answer is yes numerically (rule of law increased from -0.72 to -0.61 ) but no statistically (the change is insignificant at any significance level below 11\%). However, if we split the sample into two equally sized groups-a high-growth group with adjusted growth rates above the median of $2.6 \%$ and a low-growth group with adjusted growth below the median-then the high-growth group has experienced a statistically significant increase in institutional quality, while the low-growth group has not, cf. table 4. In fact, the group of high-growth countries had both better initial institutions and they experienced an increase in institutional quality throughout our sample period. This is a clear sign of the importance of institutions for a proper understanding of Africa's recent growth experience.

[Table 4 about here]

Chisholm and Cumming 2006). For instance, Chisholm and Cummins argue that lightning is the direct cause of one third of all U.S. power quality disturbances.

${ }^{16}$ Rule of law for all years 1996-2011 can be from http://info.worldbank.org/governance/wgi/index.asp. 
In light of table 4, the next obvious question is to ask whether adding changes in institutions to the growth regression increases explanatory power. Table 5 reports results with a variable measuring changes in institutional quality included. Inspection of the table reveals that including the change in institutions variable increases the explanatory power of the regression substantially. Compared to columns 1 and 2 of table 2, where only the level of rule of law is included, the R-squared jump from 0.173 to 0.296 and from 0.233 to 0.337 , respectively, depending on whether we use non-adjusted or adjusted data. That is, with changes in rule of law included we always increase explanatory power by more than ten percentage points. In terms of economic impact, column 2 of table 5 gives that one standard deviation increase in changes in rule of law is associated with a 0.36 standard deviations increase in adjusted growth. The other variables do not change in terms of economic significance in any material way compared to table 2. In sum, including changes in institutions does not change any of the conclusions above. Moreover, while table 5 shows that both the level of institutional quality and the change that has occurred since the start of the period are important predictors of economic growth, reverse causality does loom uncomfortably in the background when it comes to the change in institutional quality.

[Table 5 about here]

So far we have shown that two different measures of institutions, which only correlate moderately, strongly predict which African countries have grown fastest over the period 19952007 in a standard growth regression framework. This holds both in OLS, LAD, and 2LS settings. We now turn to an analysis of the period after the global financial crisis, 2008-2011.

\section{Growth in Africa since 2008}

According to the IMF's Regional Economic Outlook for Sub-Saharan African (2012), Africa's growth has remained robust against the backdrop of the sluggish global economy. We expect that better institutions increase the likelihood of a smooth adjustment following an adverse shock, such as the recent financial crisis, which otherwise could upset a budding growth takeoff (Johnson, Ostry, and Subramanian 2007). Consequently, if differences in institutions also predict differences in Africa's post global financial crisis growth, then this would make the above account, where institutions occupy center stage, even more compelling.

Our growth rates for the most recent period 2008-2011 are taken from the Regional Economic Outlook (April 2012, table SA.4). We lose one observation, Mauritania, and we cannot construct adjusted growth rates, as we have no nightlights data for this period. As shown in figure 5, the correlation between adjusted growth 1995-2007 and the IMF-based growth rates 2008-2011 is non-trivial (correlation coefficient $=0.29, p$-value 0.08 ). 
[Figure 5 about here]

Table 6 reports the regression results. Columns 1 and 2 provide OLS estimates, which are similar to those in tables 2 and 3. Both rule of law and CPIA significantly predict African real GDP per capita growth over the 2008-2011 period. The same goes for the LAD estimations in columns 3 and 4 . When it comes to 2SLS, the instrument is so weak in both columns 5 and 6 that it is of little use. The weak identification issue was to be expected: We know that institutions predict GDP growth over the period 1995-2007, for which reason initial GDP per capita in 2008 (include in table 5) will be higher (partially) correlated with institutions than initial real GDP per capita in 1995 (included in tables 2 and 3). Thus, there is in effect less institutional variation left for the instrument to explain. Nevertheless, rule of law passes the Anderson-Rubin test while CPIA does not.

Turning to economic significance, using respectively columns 1 and 2 of table 6 we get that one standard deviation increase in institutions lead to respectively 0.51 and 0.55 standard deviations increase in economic growth. The growth regression thus features structural stability in the sense that nothing seems to change after the financial crisis.

[Table 6 about here]

\section{Concluding remarks}

In this paper, we have shown that institutional differences predict growth variations in Africa during the period from 1995 to 2011. This holds for various measures of economic growth and for different measures of institutional quality; it holds in OLS, 2LS and LAD settings; and it holds for the period before and the period after the global financial crisis.

We believe that these findings constitute compelling evidence that institutions are an important part of Africa's recent growth success. This, in turn, makes us optimistic that Africa's recent growth is sustainable. 


\section{References}

Acemoglu, D. (2009): “An Introduction to Modern Economic Growth," Princeton University Press

Acemoglu, D., S. Johnson, \& J. A. Robinson (2001): "The Colonial Origins of Development: An Empirical Investigation," American Economic Review, 91, 1369-1401.

Andersen, T. B., \& C.-J. Dalgaard (2013): "Power Outages and Economic Growth in Africa," Energy Economics, 38, 19-23.

Arbache, J., \& J. Page (2009): “How Fragile is Africa's Recent Growth?" Journal of African Economies, 19, 1-24.

Beny, L., \& L. Cook (2009): “Metals or Management? Explaining Africa's Recent Economic Growth Performance," American Economic Review: Papers \& Proceedings, 99, 268-274.

Bromley, D, \& Y. Yao (2006): “Understanding China's Economic Transformation: Are there lessons for the developing world?", World Economics, 7, 73-95.

Chisholm, W., \& K. Cummins (2006): "On the Use of LIS/OTD Flash Density in Electric Utility Reliability Analysis," Proceedings of the LIS International Workshop, MSFC, Huntsville, AL. September.

Collier, P. (2007): “The Bottom Billion”, Oxford University Press.

Easterly, W., \& R. Levine (2003): "Tropics, Germs, and Crops: How Endowments Influence Economic Development," Journal of Monetary Economics, 50, 3-39.

Easterly, W. (2005): "National Policies and Economic Growth: A Reappraisal", Handbook of Economic Growth, Chapter 15, Volume 1A, Edited by Philippe Aghion and Steven N. Durlauf.

Evans, P. (2004): "Development as Institutional Change: The Pitfalls of Monocropping and the Potentials of Deliberation", Studies in Comparative International Development, 38, 30-52.

Henderson, V., A. Storeygard, \& D. Weil (2012): "Measuring Economic Growth from Outer Space," American Economic Review, 102, 994-1028.

Hausmann, R., L. Pritchett, \& D. Rodrik (2005): “Growth Accelerations," Journal of Economic Growth, 10, 303-329.

Johnson, S., J. Ostry, \& A. Subramanian (2007): "The Prospects for Sustained Growth in Africa: Benchmarking the Constraints," IMF Working Paper, March, WP/07

Kaufmann, D., A. Kraay, \& M. Mastruzzi (2010): “The Worldwide Governance Indicators," Policy Research Working Paper 5430, World Bank 
Leke, A., S. Lund, C. Roxburgh, \& A. van Wamelen (2010): "Lions on the move: The progress and potential of African economies," McKinsey Global Institute, June

Mankiw, N., (1995): "The Growth of Nations," Brookings Papers on Economic Activity 1, 275326.

McGragnaghan, M., E. Gunther, \& T. Laughner (2002): “Correlating PQ disturbances with lightning strikes," Power Quality Magazine 67, 8-13.

Mswane, L., \& C. T. Gaunt (2005): "Lightning performance improvement of the Swaziland electricity board transmission system (66kV \& $132 \mathrm{kV}$ lines) - results of the pilot project," Power Engineering Society Inaugural Conference and Exposition in Africa 2005 IEEE, 364-370

North, D. (1990): "Institutions, institutional change, and Economic development," Cambridge: Cambridge University Press

Qian, Y. (2003): "How Reform Worked in China", in Dani Rodrik, editor, In Search of Prosperity: Analytic Narratives on Economic Growth, Princeton University Press, 2003, 297-333.

Rodrik, D., A. Subramanian, \& F. Trebbi (2004): "Institutions Rule: The Primacy of Institutions over Geography and Integration in Economic Development," Journal of Economic Growth, 9, 131-165.

Rodrik, D. (2006): "Goodbye Washington Consensus, Hello Washington Confusion? A Review of the World Bank's Economic Growth in the 1990s: Learning from a Decade of Reform", Journal of Economic Literature, XLIV, 973-987.

Sachs, J., (2003): “Institutions Don't Rule: Direct Effects of Geography on Per Capita Income," NBER Working Paper No. 9490.

Wooldridge, J. (1995): "Score Diagnostics for Linear Models Estimated by Two Stage Least Square," in Advances in Econometrics and Quantitative Economics, ed. G. Maddala, P. C. B. Phillips, \& T. N. Srinivasan, Oxford: Blackwell, 66-87.

Wooldridge, J. (2010): “Econometric Analysis of Cross Section and Panel Data," Cambridge: MIT Press, 2e. 
Table 1: Summary statistics for main sample

\begin{tabular}{llllll}
\hline & Obs. & Mean & Std. Dev. & Min & Max \\
\hline Adjusted growth & 38 & 2.749 & 1.586 & 0.144 & 7.595 \\
Rule of law & 38 & -0.481 & 0.623 & -1.504 & 1.234 \\
CPIA & 31 & 3.094 & 0.448 & 2.200 & 3.900 \\
Initial GDP per capita & 38 & 6.993 & 0.875 & 5.050 & 9.331 \\
Total natural resource rent & 38 & 12.410 & 17.902 & 0.001 & 67.070 \\
Eurfrac & 38 & 0.041 & 0.144 & 0.000 & 0.700 \\
\hline
\end{tabular}


Table 2: Regression results using the rule of law indicator (1995-2007)

\begin{tabular}{lllll}
\hline & $(1)$ & $(2)$ & $(3)$ & $(4)$ \\
Estimator & OLS & OLS & LAD & 2SLS \\
Unependent variable & $\begin{array}{l}\text { Udjusted } \\
\text { GDP growth }\end{array}$ & $\begin{array}{l}\text { Adjusted } \\
\text { GDP growth }\end{array}$ & $\begin{array}{l}\text { Adjusted } \\
\text { GDP growth }\end{array}$ & $\begin{array}{l}\text { Adjusted } \\
\text { GDP growth }\end{array}$ \\
\hline & & & & \\
Rule of law & $2.173^{* * *}$ & $1.399^{* * *}$ & $1.075^{*}$ & $5.774^{* *}$ \\
Initial GDP per capita & $(0.731)$ & $(0.402)$ & $(0.607)$ & $(2.665)$ \\
& $-1.604^{* *}$ & $-1.040^{* *}$ & $-0.986^{*}$ & $-2.931^{* *}$ \\
Total natural resource rent & $(0.687)$ & $(0.448)$ & $(0.561)$ & $(1.320)$ \\
& 0.061 & $0.044^{* *}$ & 0.034 & $0.123^{* *}$ \\
Constant & $(0.037)$ & $(0.018)$ & $(0.024)$ & $(0.059)$ \\
& $14.252^{* * *}$ & $10.140^{* * *}$ & $9.794^{* *}$ & $24.501^{* *}$ \\
& $(4.941)$ & $(3.228)$ & $(4.092)$ & $(9.733)$ \\
\hline Observations & & & & 38 \\
$R$-squared & 38 & 38 & & \\
Endogeneity test $p$-value & 0.173 & 0.237 & & 0.150 \\
K-P F stat & & & & 3.333 \\
A-R stat $p$-value & & & & 0.001 \\
\hline
\end{tabular}

Notes: Robust standard errors reported in parenthesis. Asterisks *, **, *** indicate $p<0.1, p<0.05, p<0.01$. Standard errors in column 3 are bootstrapped with 200 replications. K-P F stat refers to the Kleibergen-Paap F statistic, and A-R stat refers to the Anderson-Rubin Wald test, where $\mathrm{H}_{0}$ is 'Rule of law' $=0$. Instrument for Rule of law in column 4 is eurfrac. The endogeneity test is Wooldridge's (1995) robust score test, where $\mathrm{H}_{0}$ is that "rule of law" is exogenous. The first stage coefficients associated with column 4 is: Rule of law $=-2.963 * * *+0.379 * * *$ Initial GDP per capita $-0.016 * * *$ Total natural resources rent $+0.755^{*}$ Eurfrac. 
Table 3: Regression results using the CPIA indicator (1995-2007)

\begin{tabular}{|c|c|c|c|c|}
\hline & (1) & (2) & (3) & (4) \\
\hline \multirow[t]{2}{*}{ Estimator } & OLS & OLS & LAD & 2SLS \\
\hline & Unadjusted & Adjusted & Adjusted & Adjusted \\
\hline Dependent variable & GDP growth & GDP growth & GDP growth & GDP growth \\
\hline \multirow[t]{2}{*}{ CPIA } & $3.377 * * *$ & $1.835^{* * *}$ & $2.043 * * *$ & $5.516 * * *$ \\
\hline & $(0.871)$ & $(0.446)$ & $(0.616)$ & $(1.194)$ \\
\hline \multirow[t]{2}{*}{ Initial GDP per capita } & -1.519 & -0.662 & -0.391 & $-1.198 *$ \\
\hline & $(1.010)$ & $(0.592)$ & $(0.890)$ & $(0.672)$ \\
\hline \multirow[t]{2}{*}{ Total natural resource rent } & $0.095 * *$ & $0.057 * *$ & $0.071 * * *$ & $0.113^{* * *}$ \\
\hline & $(0.045)$ & $(0.021)$ & $(0.025)$ & $(0.032)$ \\
\hline \multirow[t]{2}{*}{ Constant } & 1.175 & 0.690 & -1.930 & $-7.771 * * *$ \\
\hline & (7.982) & $(4.482)$ & $(6.867)$ & $(2.739)$ \\
\hline Observations & 31 & 31 & 31 & 31 \\
\hline$R$-squared & 0.296 & 0.347 & & \\
\hline Endogeneity test $p$-value & & & & 0.174 \\
\hline K-P F stat & & & & 10.76 \\
\hline A-R stat $p$-value & & & & 0.000 \\
\hline
\end{tabular}

Notes: Robust standard errors reported in parenthesis. Asterisks $*, * *, * * *$ indicate $p<0.1, p<0.05, p<0.01$. Standard errors in column 3 are bootstrapped with 200 replications. K-P F stat refers to the Kleibergen-Paap $F$ statistic, and A-R stat refers to the Anderson-Rubin Wald test, where $\mathrm{H}_{0}$ is $\mathrm{CPIA}=0$. Instrument for CPIA in columns 4 is eurfrac. The endogeneity test is Wooldridge's (1995) robust score test, where $\mathrm{H}_{0}$ is that CPIA is exogenous. The first stage coefficients associated with column 4 is: CPIA $=3.036^{* * *}+0.029$ Initial GDP per capita $-0.013^{* * *}$ Total natural resources rent $+0.923 * * *$ Eurfrac. 
Table 4: Institutional change in high- and low-growth countries

\begin{tabular}{llll}
\hline & $\begin{array}{l}(1) \\
\text { Rule of law } \\
1996\end{array}$ & $\begin{array}{l}(2) \\
\text { Rule of law } \\
2007\end{array}$ & $\begin{array}{l}(3) \\
\Delta \text { Rule of law }\end{array}$ \\
\hline & & & \\
Low-growth countries & $-0.863^{* * *}$ & $-0.823^{* * *}$ & 0.041 \\
(n= 19) & $(0.136)$ & $(0.109)$ & $(0.092)$ \\
High-growth countries & $-0.572^{* * *}$ & $-0.391^{* * *}$ & $0.181^{*}$ \\
(n= 19) & $(0.193)$ & $(0.143)$ & $(0.100)$ \\
All countries & $-0.718^{* * *}$ & $-0.607^{* * *}$ & 0.111 \\
(n=38) & $(0.119)$ & $(0.095)$ & $(0.068)$ \\
& & & \\
\hline
\end{tabular}

Notes: Standard errors reported in parenthesis. Asterisks *,**,*** indicate $p<0.1, p<0.05, p<0.01$. $\Delta$ Rule of law refers to rule of law 2007 minus rule of law 1996. 
Table 5: Regression results with changes in institutions included

\begin{tabular}{|c|c|c|c|}
\hline & (1) & (2) & (3) \\
\hline \multirow[t]{2}{*}{ Estimator } & OLS & OLS & LAD \\
\hline & Unadjusted & Adjusted & Adjusted \\
\hline Dependent variable & GDP growth & GDP growth & GDP growth \\
\hline \multirow[t]{2}{*}{$\Delta$ Rule of law } & $2.647 * * *$ & $1.345 * *$ & $1.536 * *$ \\
\hline & $(0.816)$ & $(0.548)$ & $(0.720)$ \\
\hline \multirow[t]{2}{*}{ Rule of law } & $2.713 * * *$ & $1.673 * * *$ & $1.589 * *$ \\
\hline & $(0.719)$ & $(0.428)$ & $(0.661)$ \\
\hline \multirow[t]{2}{*}{ Initial GDP per capita } & $-1.297^{* *}$ & $-0.884 * *$ & -0.615 \\
\hline & $(0.562)$ & $(0.357)$ & $(0.547)$ \\
\hline \multirow[t]{2}{*}{ Total natural resource rent } & $0.066^{*}$ & $0.047 * *$ & $0.057 * *$ \\
\hline & $(0.036)$ & $(0.017)$ & $(0.026)$ \\
\hline \multirow[t]{2}{*}{ Constant } & $12.017 * * *$ & $9.005^{* * *}$ & $7.072 *$ \\
\hline & $(4.117)$ & $(2.598)$ & $(4.038)$ \\
\hline Observations & 38 & 38 & 38 \\
\hline$R$-squared & 0.296 & 0.337 & \\
\hline
\end{tabular}

Notes: Robust standard errors reported in parenthesis. Asterisks *, $* *, * * *$ indicate $\mathrm{p}<0.1, \mathrm{p}<0.05, \mathrm{p}<0.01$. Standard errors in column 3 are bootstrapped with 200 replications. $\Delta$ Rule of law refers to rule of law 2007 minus rule of law 1996. 
Table 6: Regression results using the rule of law and CPIA indicator (2008-2011)

\begin{tabular}{|c|c|c|c|c|c|c|}
\hline & (1) & (2) & (3) & (4) & (5) & (6) \\
\hline Estimator & OLS & OLS & LAD & LAD & 2SLS & 2SLS \\
\hline Dependent variable & \multicolumn{6}{|c|}{ Real GDP per capita growth 2008-2011 } \\
\hline \multirow[t]{2}{*}{ Rule of law } & $1.242 * *$ & & $1.453^{*}$ & & 9.420 & \\
\hline & $(0.528)$ & & $(0.823)$ & & $(13.497)$ & \\
\hline \multirow[t]{2}{*}{ CPIA } & & $2.049 * *$ & & $2.420^{*}$ & & 7.422 \\
\hline & & $(0.806)$ & & $(1.194)$ & & (6.902) \\
\hline \multirow[t]{2}{*}{ Initial GDP per capita } & $-0.586 * *$ & -0.598 & -0.683 & -0.614 & -4.003 & -2.232 \\
\hline & $(0.270)$ & $(0.511)$ & $(0.465)$ & $(0.683)$ & $(5.921)$ & (2.523) \\
\hline \multirow[t]{2}{*}{ Total natural resource rent } & $0.030 * *$ & $0.044 * *$ & 0.039 & 0.048 & 0.179 & 0.140 \\
\hline & $(0.015)$ & $(0.017)$ & $(0.023)$ & $(0.031)$ & $(0.262)$ & (0.133) \\
\hline \multirow[t]{2}{*}{ Constant } & $5.398 * * *$ & -1.743 & $5.812^{*}$ & -2.467 & 28.964 & -9.836 \\
\hline & $(1.842)$ & $(2.281)$ & (3.206) & (3.088) & $(40.315)$ & (8.548) \\
\hline Observations & 37 & 30 & 37 & 30 & 37 & 30 \\
\hline R-squared & 0.119 & 0.185 & & & & \\
\hline K-P F stat & & & & & 0.371 & 0.616 \\
\hline A-R stat $p$-value & & & & & 0.002 & 0.262 \\
\hline
\end{tabular}

Notes: Robust standard errors reported in parenthesis. Asterisks $*, * *, * * *$ indicate $\mathrm{p}<0.1$, $p<0.05, p<0.01$. Standard errors in column 3 are bootstrapped with 200 replications. K-P FStatistic refers to the Kleibergen-Paap $F$ statistic, and A-R test refers to the Anderson-Rubin Wald test, where $\mathrm{H}_{0}$ is "institutions" $=0$. Instrument for institutions in columns 5 and 6 is eurfrac. 
Figure 1: Partial regression plot

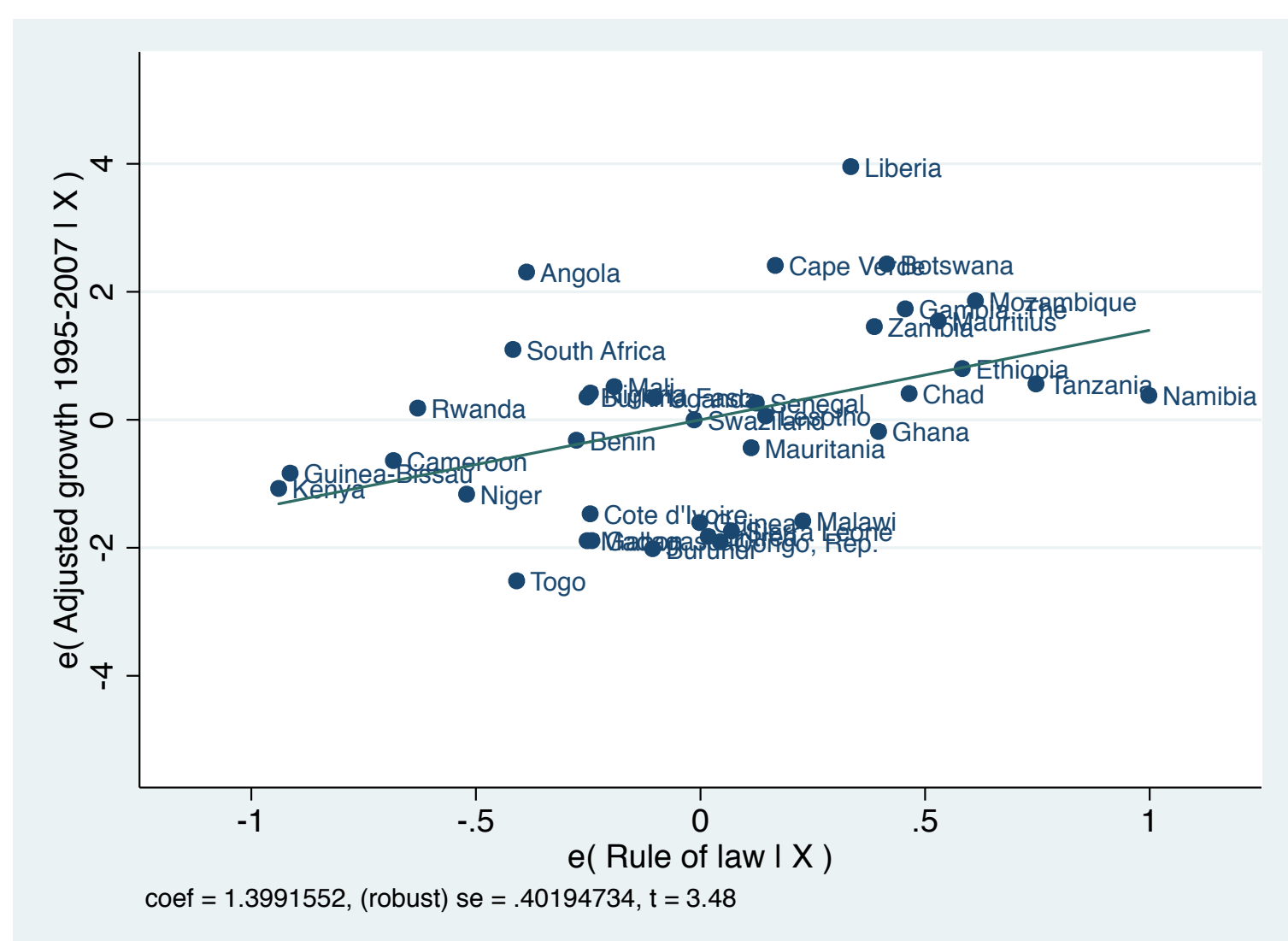

Notes: The figure plots the partial correlation between rule of law and adjusted growth based on column 2 of table 2. 
Figure 2: Correlation between CPIA and rule of law

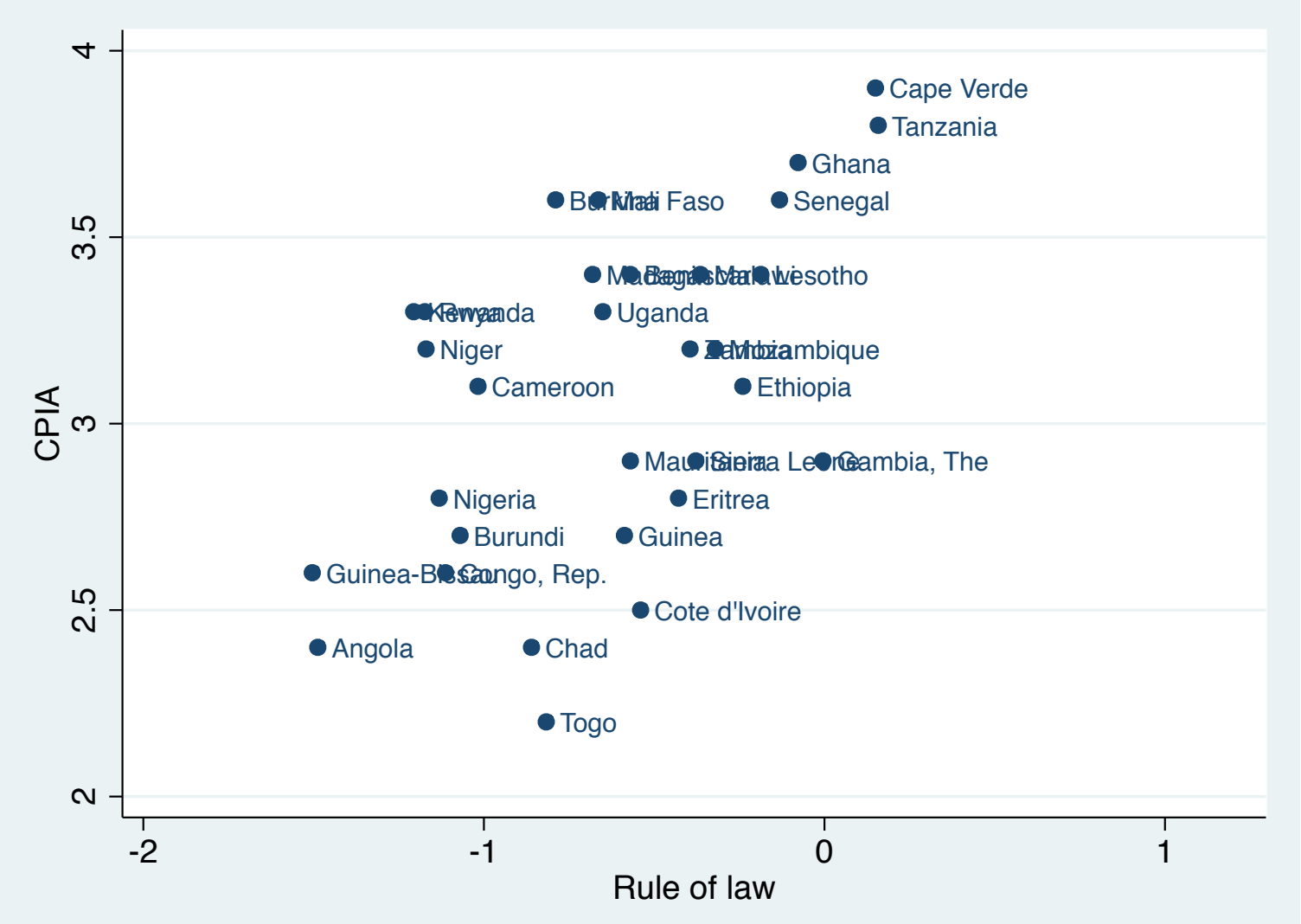

Notes: The figure plots the correlation between rule of law and CPIA for the 31 countries for which we have CPIA information (correlation coefficient $=0.53, p$-value 0.002 ) 
Figure 3: Partial regression plot

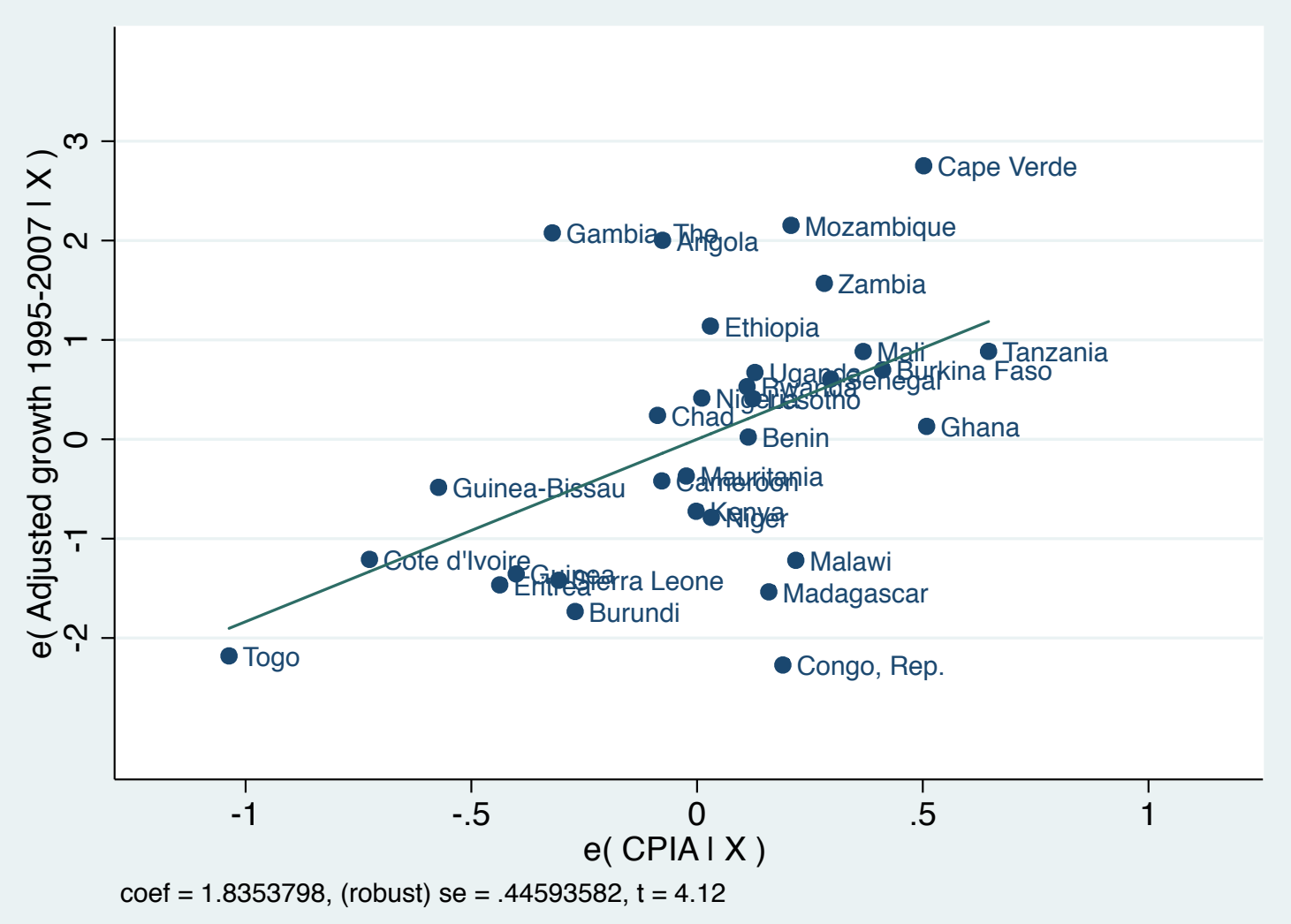

Notes: The figure plots the partial correlation between rule of law and adjusted growth based on column 2 of table 3. 


\section{Figure 4: Correlation plot}

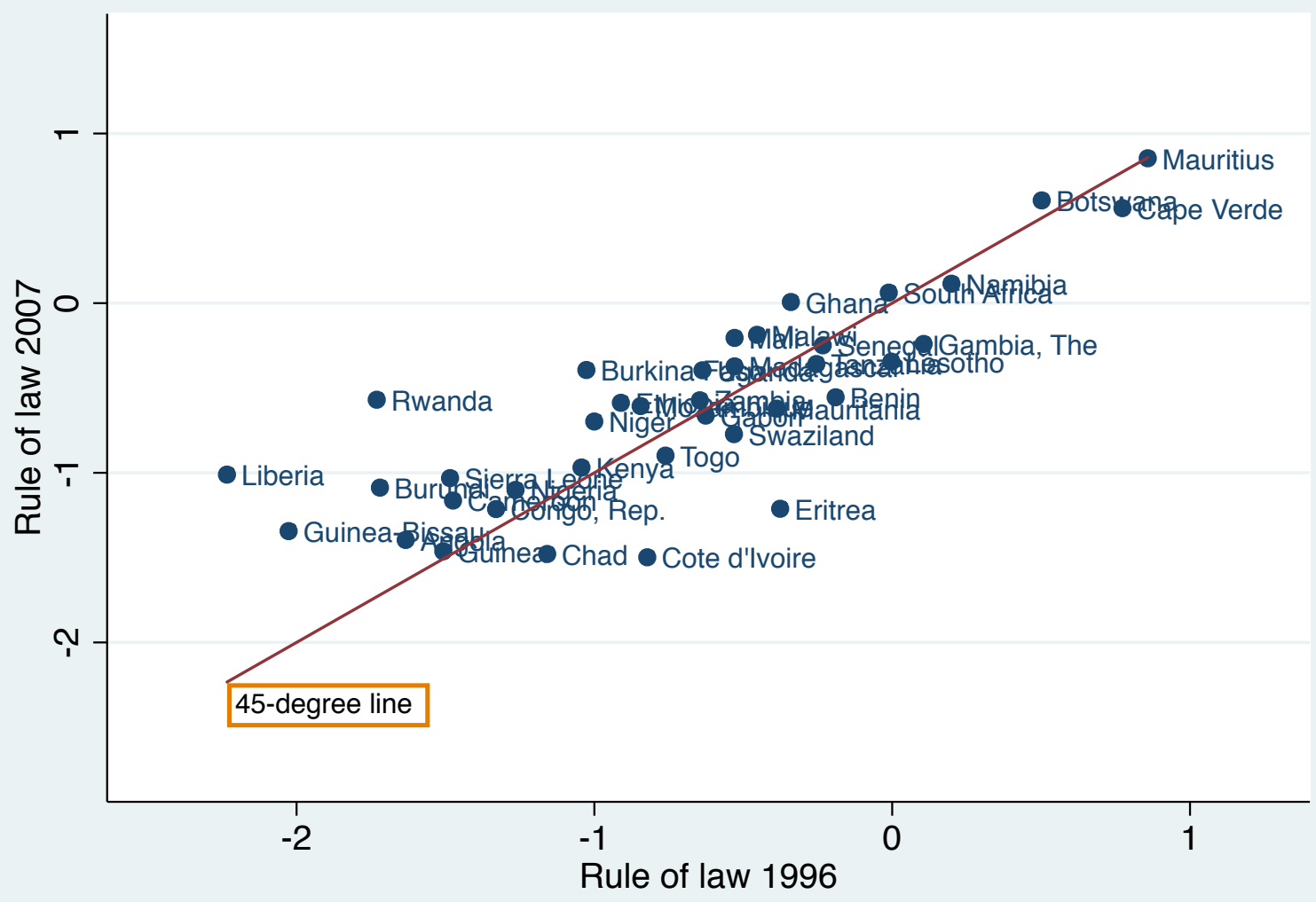

Notes: The figure plots the rule of law in 1996 versus rule of law in 2007. The correlation between the two measures is 0.82 and the full line is the 45 -degree line. 
Figure 5: Correlation plot

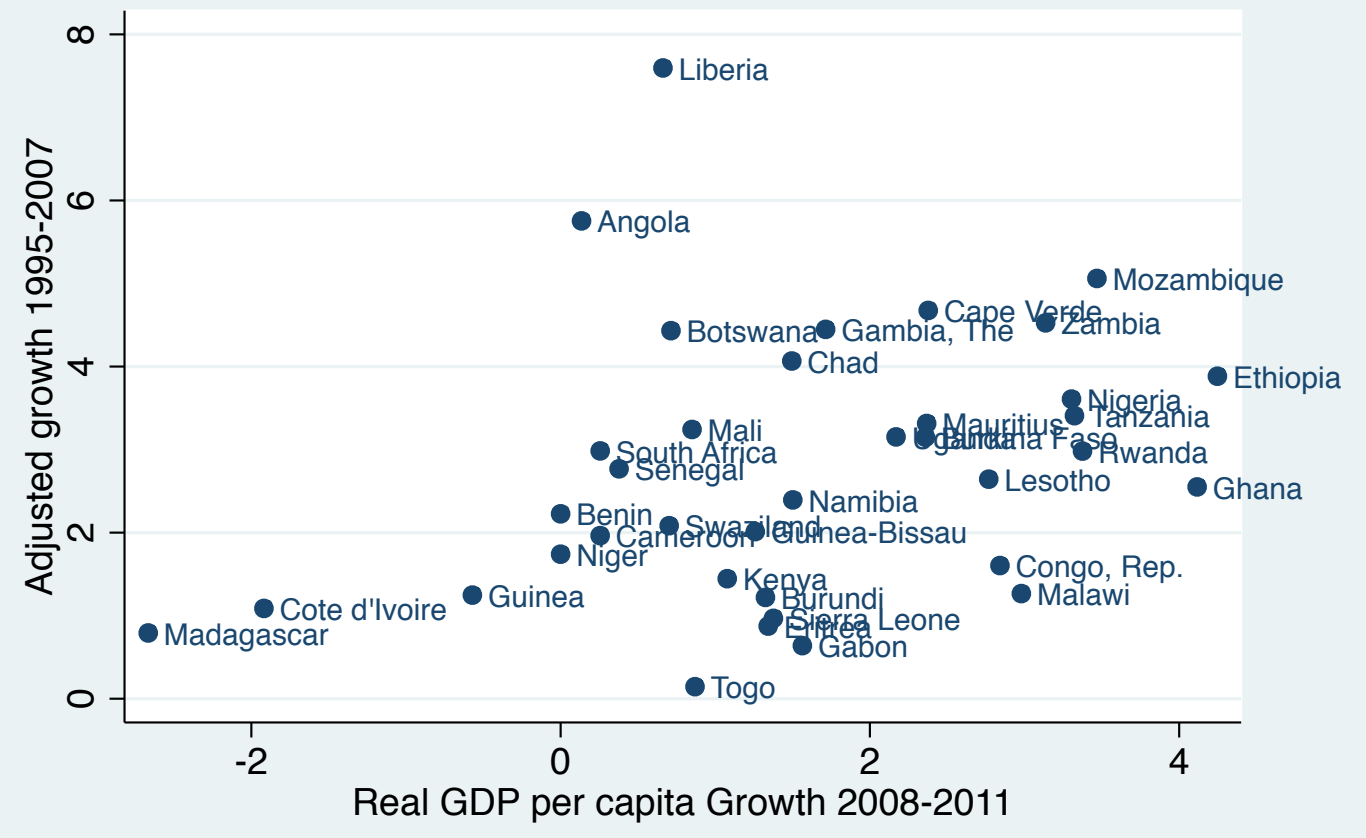

Notes: The figure plots the correlation between IMF-based real GDP per capita growth 20082011 and adjusted growth 1995-2007 (correlation coefficient $=0.29, p$-value 0.08). 


\section{Appendix}

\section{Table A.1: Robustness to climate/geographic factors}

\begin{tabular}{|c|c|c|c|c|c|c|c|c|}
\hline & (1) & (2) & (3) & (4) & (5) & (6) & (7) & (8) \\
\hline VARIABLES & \multicolumn{8}{|c|}{ Adjusted growth (1995-2007) } \\
\hline \multirow[t]{2}{*}{ Rule of law } & $1.161^{* *}$ & $1.370 * * *$ & $1.083 * *$ & $1.005^{* *}$ & & & & \\
\hline & $(0.455)$ & $(0.410)$ & $(0.448)$ & $(0.479)$ & & & & \\
\hline \multirow[t]{2}{*}{ CPIA } & & & & & $1.524 * * *$ & $1.820 * * *$ & $1.717^{* * *}$ & $1.492 * * *$ \\
\hline & & & & & $(0.406)$ & $(0.441)$ & $(0.425)$ & $(0.420)$ \\
\hline \multirow[t]{2}{*}{ Initial GDP per capita } & $-0.999 * *$ & $-1.062 * *$ & $-1.044 * *$ & $-1.015^{* *}$ & -0.503 & -0.655 & -0.572 & -0.475 \\
\hline & $(0.491)$ & $(0.451)$ & $(0.426)$ & $(0.486)$ & $(0.517)$ & (0.598) & $(0.526)$ & (0.499) \\
\hline \multirow[t]{2}{*}{ Total natural ressource rent } & $0.053^{* * *}$ & $0.045^{* *}$ & $0.046 * *$ & $0.053^{* * *}$ & $0.061 * * *$ & $0.057^{* *}$ & $0.056^{* *}$ & $0.060 * * *$ \\
\hline & $(0.017)$ & $(0.018)$ & $(0.017)$ & $(0.017)$ & $(0.016)$ & $(0.021)$ & $(0.020)$ & $(0.016)$ \\
\hline \multirow[t]{2}{*}{ Lightning density } & $-0.056^{*}$ & & & -0.048 & $-0.061 * *$ & & & $-0.055^{*}$ \\
\hline & $(0.031)$ & & & $(0.032)$ & $(0.027)$ & & & $(0.029)$ \\
\hline \multirow[t]{2}{*}{ Malaria ecology } & & -0.014 & & -0.005 & & -0.010 & & -0.005 \\
\hline & & $(0.027)$ & & $(0.024)$ & & $(0.018)$ & & (0.019) \\
\hline \multirow[t]{2}{*}{ Distance to equator } & & & $0.046^{*}$ & 0.026 & & & 0.042 & 0.018 \\
\hline & & & $(0.027)$ & $(0.025)$ & & & $(0.029)$ & $(0.031)$ \\
\hline \multirow[t]{2}{*}{ Constant } & $10.482^{* * *}$ & $10.430 * * *$ & $9.462 * * *$ & $10.165^{* * *}$ & 1.469 & 0.818 & 0.038 & 1.173 \\
\hline & $(3.380)$ & $(3.275)$ & (3.181) & $(3.400)$ & (3.568) & $(4.486)$ & $(4.028)$ & $(3.402)$ \\
\hline Observations & 38 & 38 & 38 & 38 & 31 & 31 & 31 & 31 \\
\hline R-squared & 0.311 & 0.242 & 0.273 & 0.322 & 0.459 & 0.351 & 0.384 & 0.467 \\
\hline
\end{tabular}

Notes: All estimations are by OLS. Robust standard errors reported in parenthesis. Asterisks $*, * *, * * *$ indicate $\mathrm{p}<0.1, \mathrm{p}<0.05, \mathrm{p}<0.01$. 


\section{Table A.2: Robustness to demographic factors}

\begin{tabular}{|c|c|c|c|c|c|c|c|c|}
\hline & (1) & (2) & (3) & (4) & (5) & (6) & (7) & (8) \\
\hline VARIABLES & \multicolumn{8}{|c|}{ Adjusted growth (1995-2007) } \\
\hline Rule of law & $\begin{array}{c}1.372^{* * *} \\
(0.402)\end{array}$ & $\begin{array}{c}1.357^{* * *} \\
(0.407)\end{array}$ & $\begin{array}{c}1.384 * * * \\
(0.373)\end{array}$ & $\begin{array}{c}1.335^{* * *} \\
(0.384)\end{array}$ & & & & \\
\hline CPIA & & & & & $\begin{array}{c}1.732 * * * \\
(0.481)\end{array}$ & $\begin{array}{c}1.629 * * * \\
(0.477)\end{array}$ & $\begin{array}{c}1.921 * * * \\
(0.453)\end{array}$ & $\begin{array}{c}1.650 * * * \\
(0.446)\end{array}$ \\
\hline Initial GDP per capita & $\begin{array}{l}-1.062^{*} \\
(0.524)\end{array}$ & $\begin{array}{c}-1.070^{* *} \\
(0.508)\end{array}$ & $\begin{array}{c}-1.050 * * \\
(0.495)\end{array}$ & $\begin{array}{l}-1.038 * \\
(0.550)\end{array}$ & $\begin{array}{l}-0.419 \\
(0.716)\end{array}$ & $\begin{array}{l}-0.463 \\
(0.673)\end{array}$ & $\begin{array}{l}-0.794 \\
(0.557)\end{array}$ & $\begin{array}{l}-0.601 \\
(0.705)\end{array}$ \\
\hline Total natural ressource rent & $\begin{array}{c}0.044^{* *} \\
(0.018)\end{array}$ & $\begin{array}{c}0.045^{* *} \\
(0.018)\end{array}$ & $\begin{array}{c}0.044^{* *} \\
(0.018)\end{array}$ & $\begin{array}{c}0.046 * * \\
(0.020)\end{array}$ & $\begin{array}{c}0.056^{* * *} \\
(0.019)\end{array}$ & $\begin{array}{c}0.055^{* * *} \\
(0.019)\end{array}$ & $\begin{array}{c}0.061^{* *} \\
(0.023)\end{array}$ & $\begin{array}{c}0.057^{* *} \\
(0.022)\end{array}$ \\
\hline Population $0-14$ (\% of total) & $\begin{array}{l}-0.013 \\
(0.080)\end{array}$ & & & $\begin{array}{c}0.225 \\
(0.538)\end{array}$ & $\begin{array}{c}0.208 \\
(0.132)\end{array}$ & & & $\begin{array}{l}-0.127 \\
(0.402)\end{array}$ \\
\hline Population $15-64$ (\% of total) & & $\begin{array}{c}0.023 \\
(0.090)\end{array}$ & & $\begin{array}{c}0.265 \\
(0.615)\end{array}$ & & $\begin{array}{c}-0.276^{* *} \\
(0.133)\end{array}$ & & $\begin{array}{l}-0.409 \\
(0.392)\end{array}$ \\
\hline Total population (log) & & & $\begin{array}{l}-0.034 \\
(0.221)\end{array}$ & $\begin{array}{l}-0.076 \\
(0.232)\end{array}$ & & & $\begin{array}{l}-0.135 \\
(0.225)\end{array}$ & $\begin{array}{l}-0.088 \\
(0.244)\end{array}$ \\
\hline Constant & $\begin{array}{l}10.879 \\
(6.630)\end{array}$ & $\begin{array}{l}9.101^{* *} \\
(3.749)\end{array}$ & $\begin{array}{c}10.735^{*} \\
(6.342)\end{array}$ & $\begin{array}{l}-12.649 \\
(55.966)\end{array}$ & $\begin{array}{r}-10.053 \\
(8.778)\end{array}$ & $\begin{array}{l}14.287^{*} \\
(7.037)\end{array}$ & $\begin{array}{c}3.405 \\
(5.270)\end{array}$ & $\begin{array}{c}29.150 \\
(37.399)\end{array}$ \\
\hline Observations & 38 & 38 & 38 & 38 & 31 & 31 & 31 & 31 \\
\hline R-squared & 0.238 & 0.239 & 0.238 & 0.246 & 0.407 & 0.428 & 0.358 & 0.437 \\
\hline
\end{tabular}

Notes: All estimations are by OLS. Robust standard errors reported in parenthesis. Asterisks *,**,*** indicate $\mathrm{p}<0.1, \mathrm{p}<0.05, \mathrm{p}<0.01$. 